\title{
Rapid assessment of lichen diversity in Baliem Valley, Jayawijaya, Papua, Indonesia
}

\author{
SUHARNO ${ }^{1,2, \boldsymbol{v}}$, LINUS Y. CHRYSTOMO ${ }^{1}$, PUGUH SUJARTA ${ }^{1}$, ROSYE H.R. TANJUNG ${ }^{1,3}$ \\ ${ }^{1}$ Department of Biology, Faculty of Mathematics and Natural Sciences, Universitas Cenderawasih. Jl. Kamp Wolker, Perumnas 3, Waena, Jayapura \\ 99351, Papua, Indonesia. Tel./fax. +62-967-572115, `email: harn774@yahoo.com \\ ${ }^{2}$ Biology Graduate Program, Faculty of Mathematics and Natural Sciences, Universitas Cenderawasih. Jl. Kamp Wolker, Perumnas 3, Waena, Jayapura \\ 99351, Papua, Indonesia \\ ${ }^{3}$ Center for Environmental Studies, Universitas Cenderawasih. Jl. Kamp Wolker, Perumnas 3, Waena, Jayapura 99351, Papua, Indonesia
}

Manuscript received: 10 February 2020. Revision accepted: 9 May 2020.

\begin{abstract}
Suharno, Chrystomo LY, Sujarta P, Tanjung RHR. 2020. Rapid assessment of lichen diversity in Baliem Valley, Jayawijaya, Papua, Indonesia. Biodiversitas 21: 2403-2409. Lichen is a form of mutualistic symbiosis between phycobiont and mycobiont. Lichens play an important role in environment, either to maintain the biological diversity and the function of ecosystems. This study is aimed to determine the diversity of species of lichens in the Baliem Valley region, Jayawijaya, Papua. The method used was explorative surveys in several villages in Jayawijaya District. Species identification was based on morphological characteristics. The results showed that there were 37 species of lichen belong to 24 genera and 11 families on several habitats on altitude ranging from 1655 to $2179 \mathrm{~m}$ asl with temperatures between $18-26^{\circ} \mathrm{C}$. The dominant species were from the families of Parmeliaceae, Cladoniaceae, and Teloschistaceae. The results indicate that the Baliem Valley region rich in lichen diversity and the existence of particular lichen species suggests that the region has healthy environmental conditions. This study provides new information on the existence of lichen diversity in Papua.
\end{abstract}

Keywords: Baliem valley, lichens, symbiosis, Jayawijaya

\section{INTRODUCTION}

Tropical rain forests have ecosystems with complex dynamics that contain a variety of habitats for the life of various species. As a country located in tropical region, Indonesia is rich in biological resources, including in Papua (Agustini et al. 2015; Kadir et al. 2020). Papua has a high diversity of ecosystems, ranging from beaches, lowlands, highlands, to mountains and even snow despite it is located in the equator (Kartikasari et al. 2013; Agustini et al. 2015). Papua's highland forest ecosystem has a unique vegetation structure.

Despite the importance of Papuan forests in harboring biological diversity, some forest areas in Papua have experienced deforestation and forest degradation due to regional development of regional land conversion for other land uses, such as housing, plantations, and agriculture. These changes can affect forest ecosystems and flora that grow in them (Agustini et al. 2015), including lichen (Sujetovienè 2017).

Lichen is a classic example of flora that lives in a symbiotic mutualism (Seckbach and Grube 2010). It originates from a mutualistic association between biotrophic fungi (mycobiont) and photosynthetic microorganisms (photobionts, for example, chlorophytes and/or cyanobacteria) (Goward and Arsenault 2000; Muggia and Grube 2018). Lichens play an important role in environment, either to maintain the biological diversity and the function of ecosystems, such as providing nesting, food, and shelter for other organisms (Esseen and Renhorn 1998; Singh 2011; Ellis and Coppins 2006). Moreover, when lichens are in the form of litter, they become an important source of nitrogen and iron in forest ecosystems (Begon et al. 2006; Jovan 2008), as well as an important element in nutrient cycling (Esseen and Renhorn 1998). Lichens have important values as ecological indicators through their sensitivity to various kinds of environmental stressors such as air quality and climate change (Jovan 2008; State et al. 2011; Sujetovienè 2017; Tarasova et al. 2017). Lichens also serve as biotic pioneers of terrestrial habitats (Firdous et al. 2017; Hardini et al. 2018).

Lichens can be found from the tropics to the polar regions (McMullin and Andersen 2014). Lichen habitats are very diverse, ranging from soil, rock surfaces, and trees or various other substrates in various locations, ranging from newly cleared forest land, burnt forests even to traces of volcanic lava flows (Temina and Nevo 2009; Balaji and Hariharan 2013; Firdous et al. 2017). They do not require complex living conditions as other species need (Hardini et al. 2018). There are several cosmopolitan and highly adaptable lichens that can be found in various types of world ecosystems. However, the general nature of lichens vegetation in an area is determined mainly by variations in climate and altitude (Bruun et al. 2006; Grytnes et al. 2006).

Around 25,000 species of lichens have been identified globally (Chapman 2009; Fidous et al. 2017). On the island of New Guinea (Papua New Guinea and Papua, Indonesia) at least 495 species from 126 genera have been described (Streimann 1986). This number is likely to increase as more botanical explorations and accurate identification works with molecular techniques are conducted (Orock et 
al. 2012). In Indonesia, the exploration of diversity in lichen has not been done thoroughly (Hardini et al. 2018) including in Papua. Therefore, the purpose of this study is to determine the diversity of species of lichens in the Baliem Valley region, Jayawijaya, Papua. This study will provide new information on the existence of lichen diversity in Papua.

\section{MATERIALS AND METHODS}

\section{Research area and period}

This research was conducted in the Baliem Valley region across several sub-districts in Jayawijaya District, Papua Province, Indonesia (Figure 1; Table 1), including Sub-districts of Kurulu, Tagineri, Koragi, Silokarnodoga, Asologaima, Mulianam, and Napua. Survey of the existence and diversity of lichen was conducted from October to December 2018.

\section{Survey method}

Lichen samples were collected from various types of vegetation in 7 sub-districts. The survey was conducted by exploring various areas thought to be lichen habitat, including soil, trees, twigs, leaves, and rocks. Lichen that grows on trees was also taken, although not in all locations depending on the level of ease in sampling. Each sample was given a label (number) and field identity. The specimen was dried and put into an envelope or sample collection box, then taken to the laboratory for identification.

\section{Identification of lichens}

The samples of lichen were identified based on morphological characters and reproductive characters (Huneck and Yoshimura 1999; Brodo et al. 2001; Kelly 2006; Aptroot 2009; Nimis et al. 2009; McMullin and Anderson 2014; Anon 2019). Identification used some of the latest references (i.e. Grube and Hafllner 1990; Aptroot 2009; Muggia and Grube 2018).

\section{Data analysis}

Data were analyzed qualitatively. Data are classified based on taxa groups in a table based on morphological identification results.

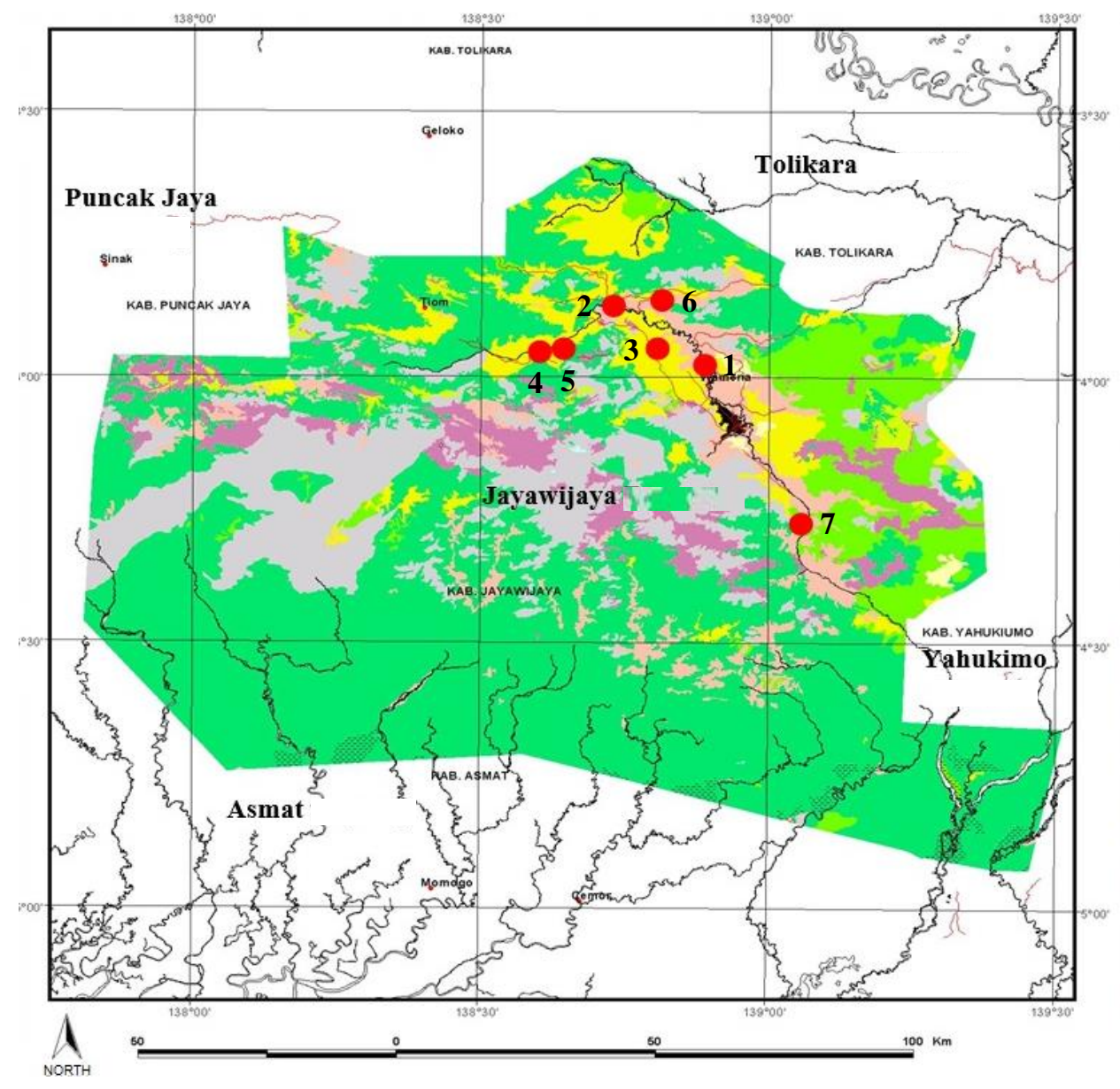

LAND COVER MAP

LUNOSAT SATEUUTE MAGE INTERPRETATON 2004
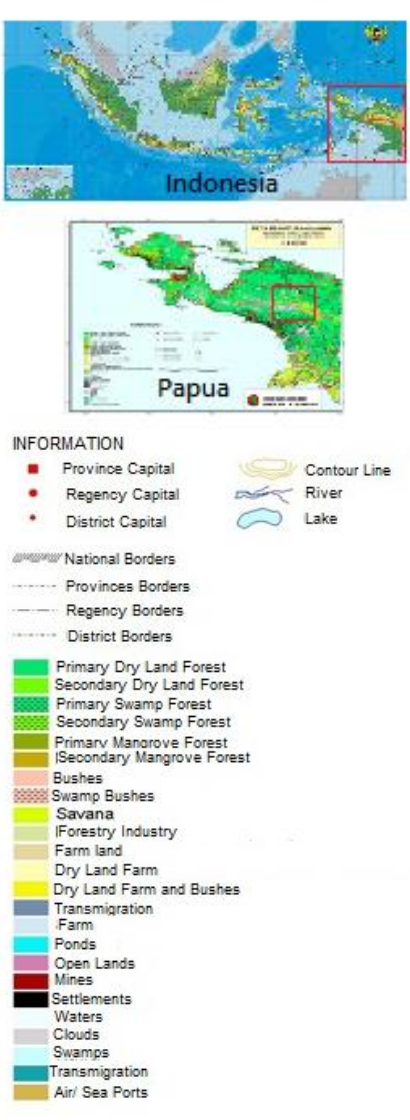

Figure 1. Study location of lichens in the Baliem Valley, Jayawijaya, Papua, Indonesia. Numbers refer to sampling sites in Table 1 
Table 1. The sampling sites of lichens in the Baliem Valley region, Jayawijaya, Papua, Indonesia

\begin{tabular}{|c|c|c|c|c|c|}
\hline No. & $\begin{array}{l}\text { Sub-district } \\
\text { (Kecamatan) }\end{array}$ & Village & $\begin{array}{l}\text { Position of } \\
\text { coordinate }\end{array}$ & $\begin{array}{c}\text { Altitude } \\
\text { (m asl.) }\end{array}$ & $\begin{array}{c}\text { Temperature } \\
\left({ }^{\circ} \mathbf{C}\right)\end{array}$ \\
\hline 1. & Kurulu & Kurulu & S: $04^{\circ} 02^{\prime} 54,4^{\prime \prime} ;$ E: $138^{\circ} 56^{\prime} 45,8^{\prime \prime}$ & 1670 & 25 \\
\hline \multirow[t]{2}{*}{2.} & Tagineri & Meleme & S: $03^{\circ} 51^{\prime} 02,5^{\prime \prime} ;$ E: $138^{\circ} 48^{\prime} 02,7^{\prime \prime}$ & 2217 & 18 \\
\hline & & Rumbepaga & & 2074 & 20 \\
\hline 3. & Koragi & Tagipaga & S: $03^{\circ} 51^{\prime} 02,5^{\prime \prime} ;$ E: $138^{\circ} 48^{\prime} 02,7^{\prime \prime}$ & 1996 & 22 \\
\hline 4. & Silokarnodoga & Apnay Kosili & S: $03^{\circ} 54^{\prime} 27,6^{\prime \prime} ;$ E: $138^{\circ} 47^{\prime} 20,0^{\prime \prime}$ & 1664 & 24 \\
\hline 5. & Asologaima & Walak & S: $03^{\circ} 54^{\prime} 49,2^{\prime \prime}$; E: $138^{\circ} 47^{\prime} 03,2^{\prime \prime}$ & 1686 & 25 \\
\hline 6. & Mulianam & Konam & S: $04^{\circ} 59^{\prime} 59,9^{\prime \prime}$; E: $138^{\circ} 48^{\prime} 29,8^{\prime \prime}$ & 1736 & 23 \\
\hline 7. & Napua & Napua & S: $04^{\circ} 06^{\prime} 59,0^{\prime \prime}$; E: $138^{\circ} 53^{\prime} 38,1^{\prime \prime}$ & 1678 & 26 \\
\hline
\end{tabular}

\section{RESULTS AND DISCUSSION}

\section{Habitat of lichens}

The sampling locations in the Baliem Valley region of Jayawijaya District, Papua Province, Indonesia, ranged in altitude, starting from $1664 \mathrm{~m}$ asl in the Apnay Kosili village of Silokarnodoga Sub-district to $2217 \mathrm{~m}$ asl in the Meleme village of Tagineri Sub-district. The temperature also varied between $18-26^{\circ} \mathrm{C}$. Altitude has strong relationship with air temperature, which affects the physiological activity of organisms (Grytnes et al. 2006; Agustini et al. 2015; Parizadeh and Garampalli 2017), including lichens (Rafat 2014; Firdous et al. 2017). For lichens, altitude is very influential on species diversity (Baniya et al. 2010), even to the content of secondary metabolites (Temina et al. 2010).

Lichens in the studied areas were found on a variety of substrates, such as soil, rocks, trees, and twigs (Figure 2). Lichen groups that grow on trees depend on the diversity and abundance of vegetation in an area. Most of the vegetation in the highlands in Papua has a low diversity. Conversely the lower the altitude of an area, the higher diversity of plant species (Kartikasari et al. 2013). The type and condition of vegetation, and the altitude of the habitat influence lichen diversity in an area (Bruun et al. 2006), including lichen epiphytes (Teminaim et al. 2009; Baniya et al. 2010).

\section{Lichens diversity}

The results of the research in the Baliem valley, Jayawijaya Papua showed that there were 37 species of lichens belong to 25 genera recorded (Table 2; Figure 3). The observation found 11 families, which were dominated by Parmeliaceae (16 types), Cladoniaceae ( 7 types), and Teloschistaceae (4 types). Balaji and Hariharan (2013) found 103 species of macrolichens from 9 families and 27 genera in Siruvani Hills, Tamil Nadu, India. Another study from Temina and Nevo (2009) found 350 species from 52 families and 117 genera in Israel. Kusmoro et al. (2018) found 133 species from 62 genera and 17 families of lichens in Kamojang Geothermal areas. When compared with the results of the study, the level of lichen diversity in the Baliem Valley is low. Low species diversity can occur due to different methods, locations, and climate factors.
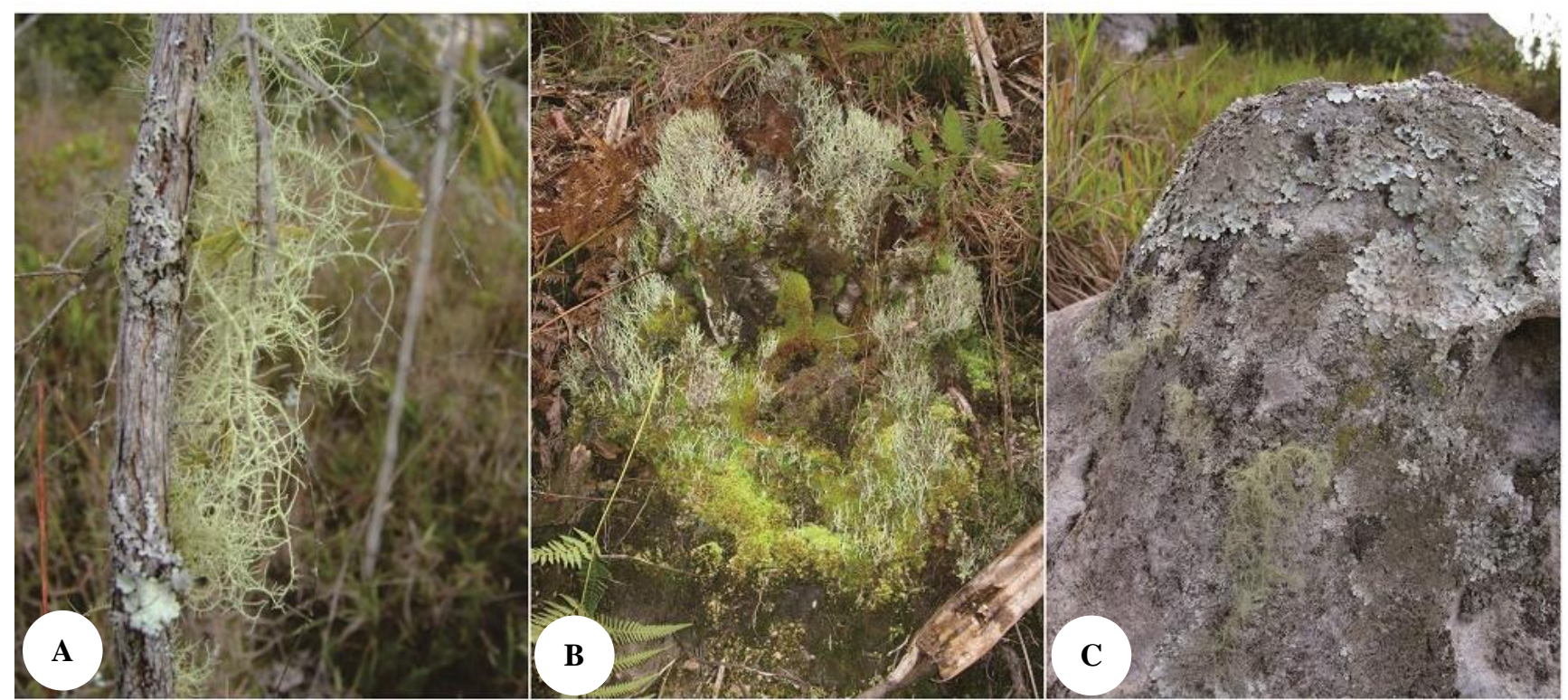

Figure 2. Habitat of lichen in Baliem Valley, Jayawijaya District, Papua Province, Indonesia: A. Branch, or tree (woods); B. Soil; C. Rock 
Based on the thallus type, lichens in the Baliem Valley region were dominated by fruticose types (16 species), and foliose (13 species), and only 8 species were found for the crustose type (Table 2). The results of the study are different from those conducted by Firdous et al. (2017) in Pakistan (Western Himalayan region) which was dominated by lichen foliose type followed by crustose, fruticose, and squamulose. The results of other studies showed a strong correlation of lichen fruticose with the altitude of location (Pinokiyo et al. 2008).

There is relatively little research on the relationship between lichen's diversity patterns and elevation (Bruun et al. 2006; Grytnes et al. 2006). However, lichen is one of the most successful organisms in extreme environments such as the cold arctic and alpine environments where most plants cannot grow (McCune and Antos 1982; Grytnes et al. 2006). Lichen also shows high diversity as epiphyte. Lichen can benefit from the diversity of trees and shrubs as substrates (Baniya et al. 2010).

Usnea is a genus of lichen that has a wide distribution throughout the world (Rafat 2014). Three species of Usnea found in the Baliem Valley were Usnea australis, Usnea sp., and $U$. longissima. These species were found on tree substrates, while $U$. longissima was also found on rocks/cliffs. From the genus of Lobaria, there were two species, namely L. pulmonaria and Lobaria sp. Lobaria pulmonaria is a type of lichen that is sensitive to air pollution. This type is often used as a parameter of air pollution. Its existence in the Baliem Valley region indicates that this region has a low level of air pollution.

Parmotrema stuppeum (foliose lichen) is a type of lichen found in the Baliem Valley. According to Louwhoff and Elix (1999), the revised biosystematics of the genus Parmotrema (Ascomycotina: Parmeliaceae) in Papua New Guinea show that this genus consists of 50 species. Twelve species are new records for Papua New Guinea and six are described as new to science, namely: Parmotrema kurolawianum, $P$. malonprotocetraricum, $P$. menyamyaense, $P$. sipmanii, $P$. verrucatum and $P$. watutense. Fourteen of the 50 species of Parmotrema are considered endemic to Papua New Guinea.

Table 2. Diversity of lichen species in the Baliem Valley region, Jayawijaya, Papua, Indonesia

\begin{tabular}{|c|c|c|c|}
\hline Family & Species & Habitat & Type of thallus \\
\hline \multirow[t]{4}{*}{ Teloschistaceae } & Polycauliona coralloides (Tuck.) Hue & Rock & Fruticose lichen \\
\hline & Flavoplaca marina (Wedd.) Arup & Rock & Crustose lichen \\
\hline & Variospora thallincola (Wedd.) Arup & Rock & Crustose lichen \\
\hline & Teloschistes flavicans (Sw.) Norman & Rock & Fruticose lichen \\
\hline \multirow{7}{*}{ Cladoniaceae } & Cladonia chlorophaea (Flörke ex Sommerf.) Sprengel. & Soil & Fruticose lichen \\
\hline & Cladonia cristatella Tuck. & Soil & Fruticose lichen \\
\hline & Cladonia floerkeana (Fr.) Flörke. & Soil & Fruticose lichen \\
\hline & Cladonia ochrochloraFlörke. & Soil & Fruticose lichen \\
\hline & Cladonia sp. & Soil & Fruticose lichen \\
\hline & Cladonia sp2. & Soil & Fruticose lichen \\
\hline & Pilophorus aciculare (Ach.) Th. Fr. & Rock & Fruticose lichen \\
\hline Caliciaceae & Dimelaena radiata (Tuck.) Müll. Arg. & Rock & Crustose lichen \\
\hline Graphidaceae & Diploschistes actinostomus (Ach.) Zahlbr. & Rock & Crustose lichen \\
\hline \multirow[t]{16}{*}{ Parmeliaceae } & Bryoria fremontii (Tuck.) Brodo \& D. Hawksw. & Rock, wood & Fruticose lichen \\
\hline & Evernia prunastri (L.) Ach. & Rock, wood & Fruticose lichen \\
\hline & Flavoparmelia caperata (L.) Hale. & Branch or tree & Foliose lichen \\
\hline & Hypogymnia imshaugii Krog. & Wood & Foliose lichen \\
\hline & Hypogymnia sp. & Wood & Foliose lichen \\
\hline & Letharia sp. & Moss, Rock & Fruticose lichen \\
\hline & Letharia vulpina (L.) Hue & Rock & Fruticose lichen \\
\hline & Parmotrema stuppeum (Taylor) Hale. & Wood & Foliose lichen \\
\hline & Platismatia sp. & Wood, rock & Foliose lichen \\
\hline & Usnea australis & Wood & Fruticose lichen \\
\hline & Usnea longissima Ach. & Rock, wood & Fruticose lichen \\
\hline & Usnea sp. & wood & Fruticose lichen \\
\hline & Parmelia sp. & Wood, rock & Foliose lichen \\
\hline & Parmelia sp.1 & Rock & Foliose lichen \\
\hline & Xanthoparmelia sp. & Rock, wood & Foliose lichen \\
\hline & Hypotrachyna catawbiensis (Degel.) Divakar & Wood & Foliose lichen \\
\hline \multirow{2}{*}{ Lecanoraceae } & Lecanora gangaleoides $\mathrm{Nyl}$. & Rock & Crustose lichen \\
\hline & Lecanora rupicola (L.) Zahlbr. & Rock, wood & Crustose lichen \\
\hline \multirow{2}{*}{ Lobariaceae } & Lobaria pulmonaria (L.) Hoffm. & Wood & Foliose lichen \\
\hline & Lobaria sp. & Wood & Foliose lichen \\
\hline Pannariaceae & Pannaria lurida (Mont.) Nyl. & Wood & Foliose lichen \\
\hline Physciaceae & Physcia millegrana Degel. & Wood, rock & Foliose lichen \\
\hline Trapeliaceae & Placopsis sp. & Rock & Crustose lichen \\
\hline Rhizocarpaceae & Rhizocarpon sp. & Wood, Branch or tree & Crustose lichen \\
\hline
\end{tabular}



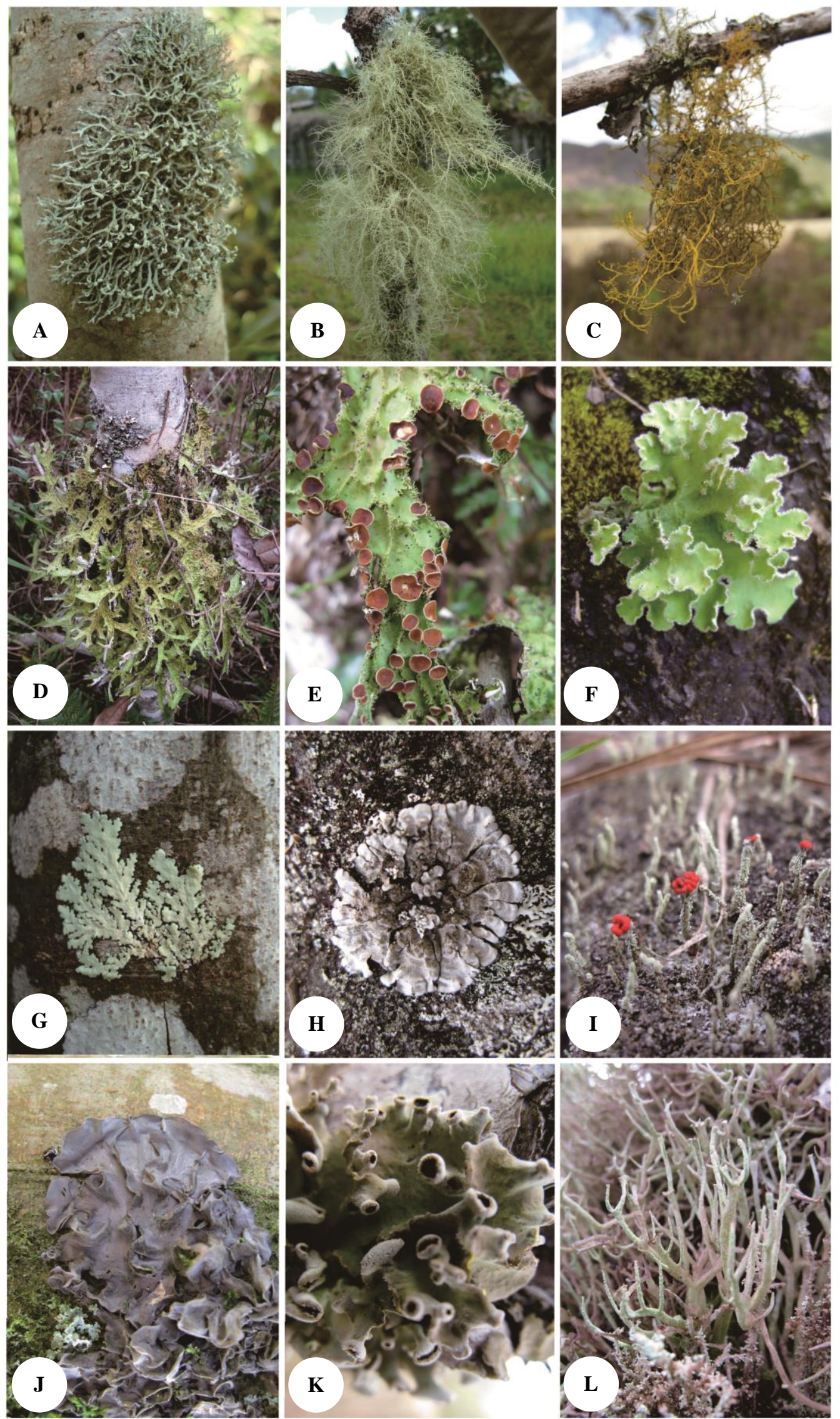

Figure 3. Diversity of lichen in Baliem Valley, Jayawijaya, Papua, Indonesia: A. Hypotrachyna catawbiensis; B. Usnea longissima: C. Teloschistes flavicans; D. Lobaria sp.; E. Lobaria pulmonaria; F. Lobaria sp2.; G. Pannaria sp.; H. Xanthoparmelia sp.; I. Cladonia sp.; J. Parmelia sp.; K. Parmelia sp.1; L. Cladonia sp.2. 
Forest sustainability has been shown to play a major role in the existence and abundance of lichen species (Sillett et al. 2000). Changes in forest succession produce different lichen habitats, primarily related to changes in light penetration, and characteristics of host's bark (McCune and Antos 1982). More complex structured forests usually have higher diversity. Old forests are structurally more complex and contain greater lichen epiphytic biomass than younger forests (Esseen and Renhorn 1998; Sillett et al. 2000). The lichen community can experience temporal change through several processes, ranging from traditional Clementsian succession to the hierarchy of competitive displacement (Kantvilas 2016). Changes in the lichen community do not reflect succession, but there may be changes in species diversity patterns due to their dispersal ability (McCune and Antos 1982; Begon et al. 2006).

These results are consistent with the findings of Müller (2001) who concluded that the diversity and distribution of lichen is strongly influenced by environmental conditions. Altitude appeared as a limiting factor governing the diversity and distribution of lichens in various habitats and microclimates. Maximum diversity was reported from high temperate locations while lower subtropical locations represent the lowest values. Furthermore, a very poor diversity of lichens correlated with intense anthropogenic disturbances, higher levels of pollution and geographic and climate conditions that were not suitable.

In the Baliem Valley region there were also Lobaria oregana and Lobaria sp. According to Jovan (2008) the group (Lobariaceae) makes an important contribution to the nutritional cycle in forest areas. This condition is supported by cyanobacteria partners in fixing atmospheric nitrogen $\left(\mathrm{N}_{2}\right)$ into a form that can be used by plants. Nitrogen input from cyanolichens may be quite large, especially in old moist forests. It is estimated that L. oregana alone fixing $16.5 \mathrm{~kg} \mathrm{~N}_{2}$. ha $^{-1}$. year $^{-1}$ at several high biomass locations in the western Cascades of Oregon. This lichen, like other species, is an important component of the ecosystem and directly affects the health of the forest. Furthermore, Jovan (2008) revealed that some species of lichens are very sensitive to environmental changes, so that they are used as bioindicators in the assessment of natural resources. Lichen is generally used as an indicator of forest health and ecological functioning, because lichen is a major producer related to the nutrient cycle and food webs in forest ecosystem.

The low discoveries of species found by rapid assessment carried out in this study suggests that further similar research is required, especially in other regions, considering lichen research is still lacking in Papua. In fact, perhaps, this research is the first in Papua. It is hoped that other species will be discovered, including new species in Papua. The results of an examination of around 3000 recent lichen collections from Papua New Guinea, 112 are known to be new records. When considering the topographical and geological conditions of the region, it is possible that the Papua still holds high lichen diversity, moreover, this kind of research has not been carried out intensively in all areas of Papua (Aptroot and Sipman 1991). For this reason, the use of molecular techniques can help to advance identification techniques. Many species of lichens are identified based on the DNA nucleotides that form lichens. Utilization of DNA in the identification process will enrich the diversity of species of lichens (Orock et al. 2012; Leavitt et al. 2013).

\section{ACKNOWLEDGEMENTS}

We would like to thank the head of Cabang Dinas Kehutanan (CDK) Wamena di Jayawijaya who had given permission for this research. We also thank Dr. Iin Supartinah Noer (Padjajaran University, Indonesia) and Dr. Maklon Warpur (Cenderawasih University, Indonesia), who had facilitated the early stage of the survey and Robert for supporting us with the facilities and personnel during the field survey.

\section{REFERENCES}

Agustini V, Sufaati S, Suharno. 2015. Anggrek Dataran Tinggi Habema di Distrik Nanggo Trikora, Jayawijaya, Papua. Jurnal Biologi Papua 7 (1): 9-15. [Indonesian]

Anon. 2019. Pictures of tropical lichens. http://www.tropicallichens.net/.

Aptroot A, Sipman, H. 1991. New lichens and lichens record from New Guinea. Willdenowia 20: 221-256.

Aptroot A. 2009. Keys to the macrolichens and checklist of the lichens and lichenicolous fungi of New Guinea. Botanischer Garten und Botanisches Museum, Berlin.

Balaji P, Hariharan GN. 2013. Diversity of Macrolichens in Bolampatti II Forest Range (Siruvani Hills), Western Ghats, Tamil Nadu, India. ISRN Biodivers 2013: 1-5.

Baniya CB, Solhøy T, Gauslaa Y, Palmer MW. 2010. The elevation gradient of lichen species richness in Nepal. Lichenologist 42 (1): 8396.

Begon M, Townsend CR, Harper JL. 2006. Ecology, from Individuals to Ecosystems. Fourth Edition. Blackwell Publishing Ltd. Victoria, Australia

Brodo, IM, Cameron R, Andrachuk H, Craig B. 2001. Identifying Lichens of Nova Scotia: A reference guidebook. EMAN Coordinating Office Environment Canada Canada Centre for Inland Waters, Canada.

Bruun HH, Moen J, Virtanen R, Grytnes JA, Oksanen L, Angerbjörn A. 2006. Effects of altitude and topography on species richness of vascular plants, bryophytes and lichens in alpin communities. J Veg Sci 17: 37-46.

Chapman AD. 2009. Numbers of Living Species in Australia and The World. Australian Biological Resources Study (ABRS), Canberra.

Ellis CJ, Coppins BJ. 2006. Contrasting functional traits maintain lichen epiphyte diversity in response to climate and autogenic succession. $\mathrm{J}$ Biogeogr 33: 1643-1656.

Esseen P.-A, Renhorn, K.-E. 1998. Mass loss of epiphytic lichen litter in a boreal forest. Ann Bot Fenn 35: 211-217.

Firdous SS, Khan S, Dar MEUI, Shaheen H, Habib T, Ullah TS. 2017. Diversity and distribution of Lichens in different ecological zones of Western Himalayas Pakistan. Bangladesh J Bot 46 (2): 805-811.

Goward T, Arsenault A. 2000. Cyanolichens and conifers: implications for global conservation. For Snow Landsc Res 75 (3): 303-318.

Grube M, Hafellner J. 1990. Studies on lichenicolous fungus of the genus Didymella (Ascomycetes, Dothideales). Nova Hedwigia 51: 283-360.

Grytnes JA, Heegaard E, Ihlen PG. 2006. Species richness of vascular plants, bryophytes, and lichens along an altitudinal gradient in western Norway. Acta Oecol 29: 241-246.

Hardini J, Kasiamdari RS, Santosa, Purnomo. 2018. New records of Graphis (Graphidaceae, Ascomycota) in Bali Island, Indonesia. Biodiversitas 19 (1): 112-118 
Huneck S, Yoshimura I. 1999. Identification of lichen substances. Springer, Berlin.

Jovan S. 2008. Lichen bioindication of biodiversity, air quality, and climate: baseline results from monitoring in Washington, Oregon, and California. Gen Tech Rep PNW-GTR-737. Portland.

Kadir A, Tanjung RHR, Suharno, Rumahorbo BT, Reza MA. 2020. Soil physicochemical and ethnobiological studies on the peat swamp forests of Southern Papua, Indonesia. Biodiversitas 21 (4): 17141722.

Kantvilas G. 2016. Observations on some tropical species of the lichen genus Mycoblastus Norman (Mycoblastaceae). Austrobaileya 9 (4): 539-545.

Kartikasari SN, Marshal AJ, Beehler BM. 2013. Ekologi Papua. Seri Ekologi Indonesia. Jilid VI. Cetakan Kedua. Penerbit Obor, Jakarta. [Indonesian]

Kelly AM. 2006. Guide to Common Macrolichens and Bryophytes of the Umatilla National Forest. United States Department of Agriculture, USA.

Kusmoro J, Noer IS, Jatnika MF, Permatasari RE, Partasasmita R. 2018. Lichen diversity in geothermal area of Kamojang, Bandung, West Java, Indonesia and its potential for medicines and dyes. Biodiversitas 19 (6): 2335-2343.

Leavitt SD, Fernández-Mendoza F, Pérez-Ortega S, Sohrabi M, Divakar PK, Lumbsch HT, St.Clair LL. 2013. DNA barcode identification of lichen-forming fungal species in the Rhizoplaca melanophthalma species-complex (Lecanorales, Lecanoraceae), including five new species. MycoKeys 7: 1-22.

Louwhoff SHJJ, Elix JA. 1999. Parmotrema and allied lichen genera in Papua New Guinea. Bibliotheca Lichenologica. Band 73. Stuttgart, Berlin.

McCune B, Antos JA. 1982. Epiphyte communities of the Swan Valley, Montana. Bryologist 85: 1-12.

McMullin RT, Anderson F. 2014. Common Lichens of Northeastern North America: A Field Guide. $1^{\text {st }}$ ed. Botanical Garden Press, New York.

Muggia L, Grube, M. 2018. Fungal diversity in Lichens: From extremotolerance to interactions with algae. Life 8: 1-15.

Müller K. 2001. Pharmaceutically relevant metabolites from lichens. Appl Microbiol Biotechnol 56 (1-2): 9-16.

Nimis PL, Wolseley P, Martellos S. 2009. A key to common lichens on trees in England. OPAL Explore Nature, England.
Orock EA, Leavitt SD, Foge BA, Clair LLST, 2012. DNA-based identification of lichen-forming fungi: can publicly available sequence databases aid in lichen diversity inventories of Mount Cameroon (West Africa)? Lichenologist 44 (6): 833-839.

Parizadeh H, Garampalli RH. 2017. Physiological and chemical analysis for identification of some lichen extracts. J Pharmacog Phytochem 6 (5): 2611-2621

Pinokiyo A, Singh KP, Singh JS. 2008. Diversity and distribution of lichens in relation to altitude within a protected biodiversity hot spot, north-east India. Lichenologist 40 (1): 47-62.

Rafat A. 2014. Ecological and Biological Studies of New Zealand Lichens in The Genus Usnea. [Thesis]. Lincoln University, New Zealand.

Seckbach J, Grube M. 2010. Symbiosis and stress: Joint ventures in biology. Springer, Berlin.

Sillett SC, McCune B, Peck JE, Rambo TR, Ruchty A. 2000. Dispersal limitations of epiphytic lichens result in species dependent on oldgrowth forest. Ecol Application 10 (3): 789-799.

Singh KP. 2011. Studies on Indian lichens during the last 50 years (19602010). Phytotaxonomy 11: 120-140.

State G, Popescu IV, Gheboianu A, Radulescu C, Dulama I, Bancuta I, Stirbescu R. 2011. Identification of air pollution elements in lichens used as bioindicators, by the XRF and AAS methods. Rom J Phys 56 (1-2): 240-249.

Streimann H. 1986. Catalogue of the lichens of Papua New Guinea and Irian Jaya. Band 22. Bibliotheca Lichenologica. Stuttgart, Berlin.

Sujetovienè G. 2017. Epiphytic lichen diversity as indicator of environmental quality in an industrial area (Central Lithuania). Pol $\mathbf{J}$ Ecol 65 (1): 38-45.

Tarasova VN, Obabko RP, Himelbrant DE, Boychuk MA, Stepanchikova IS, Borovichev EA. 2017. Diversity and distribution of epiphytic lichens and bryophytes on aspen (Populus tremula) in the middle boreal forests of Republic of Karelia (Russia). Folia Cryptog Estonica Fasc 54: 125-141.

Temina M, Levitsky DO, Dembitsky VM. 2010. Chemical constituents of the epiphytic and lithophilic lichens of the genus Collema. Rec Nat Prod 4 (1): 79-86.

Temina M, Nevo E. 2009. Lichens of Israel: diversity, ecology, and distribution. BioRisk 3: 127-136.

Teminaim IM, Andreev MP, Barinova S, Nevo E. 2009. The diversity and ecology of epiphytic lichens in "Evolution Canyon" II, Lower Nahal Keziv, Upper Western Galilee. Turk J Bot 33: 263-275. 